\title{
KOMPETENSI PROFESIONAL DAN PEDAGOGI MAHASISWA DALAM PELAKSANAAN PROGRAM PENGALAMAN LAPANGAN
}

\author{
Gito Hadiprayitno, Agus Ramdani, Jamaluddin, Karnan, dan Akhmad Sukri \\ FKIP Universitas Mataram \\ email: gitohadiprayitno@unram.ac.id
}

\begin{abstract}
Abstrak: Penelitian bertujuan untuk menganalisis kompetensi profesional dan pedagogi mahasiswa dalam pelaksanaan program pengalaman lapangan. Penelitian dilakukan terhadap 16 mahasiswa yang melaksanakannya di tujuh sekolah (SMP dan SMA). Data dikumpulkan melalui observasi dan angket. Instrumen angket terdiri atas perancangan pembelajaran, pelaksanaan pembelajaran yang mendidik dan dialogis, pemanfaatan teknologi pembelajaran, dan evaluasi hasil belajar. Data dianalisis secara kuantitatif dan kualitatif melalui analisis skor instrumen penilaian perencanaan pembelajaran, lembar kerja analisis pembelajaran (IPPP), dan angket kompetensi profesional. Hasil penelitian menunjukkan bahwa kompetensi pedagogi mahasiswa PPL dalam membuat kegiatan perencanaan pembelajaran berada dalam kategori sesuai seluruhnya (rerata 2,74), sedangkan kompetensi pedadogi dan profesional mahasiswa dalam melaksanakan kegiatan pembelajaran masuk ke dalam kategori sangat baik.
\end{abstract}

\section{Kata kunci: kompetensi profesional, kompetensi pedagogi, PPL}

\section{PROFESSIONAL AND PEDAGOGY COMPETENCE OF UNDERGRADUATE STUDENTSDURING FIELD EXPERIENCE PROGRAM}

\begin{abstract}
The purpose of this research is to analyze the professional and pedagogy competence of undergraduate students when undertaking field experience program. The research was conducted on the first semester of 2014/2015 academic year from October to December. The research sample consisted of 16 undergraduate students doingthe program at 7 schools (junior and senior high schools). Data were collected through observation and questionnaire. The questionnaire consisted of the lesson plan, educative and dialogic learning process, the use of learning technology, and evaluation of the learning results. Data were analyzed quantitatively and qualitatively by examining the score of lesson plan evaluation, learning analysis worksheet, and professional competency questionnaire. The results show that students'pedagogic competence in preparing lesson plan during the program has an average score of 2.74 (sesuaiseluruhnya or all compatible). Meanwhile, students' pedagogic and professional competence can be categorized as'very good'.
\end{abstract}

Keywords: pedagogy, professional, competence,field experience program

\section{PENDAHULUAN}

Program Pengalaman Lapangan (PPL) merupakan program dalam pendidikan prajabatan guru yang dirancang secara khusus untuk menyiapkan para calon guru menguasai kemampuan keguruan yang terintegrasi dan utuh, sehingga setelah menyelesaikan pendidikannya dan diangkat menjadi guru, seorang calon guru siap mengemban tugas dan tanggung jawabnya sebagai guru (Wardani, 1994). PPL merupakan kegiatan praktek mengajar yang dilakukan di sekolah sebagai sarana melatih mahasiswa sebagai calon guru dalam mengaplikasikan kemampuan mengajar yang secara teori telah dipelajari pada perkuliah- an. Selain itu, PPL diselenggarakan untuk membekali calon guru dengan kompetensi yang harus dikuasainya, seperti kompetensi pedagogi dan profesional dengan harapan setelah mahasiswa melakukan PPL mereka memiliki kemampuan mengajar dengan baik. Hal ini sejalan dengan Undang-undang Guru dan Dosen (UUGD) yang mempersyaratkan seorang guru harus memiliki empat kompetensi diantaranya ialah kompetensi pedagogi, profesional, sosial dan kepribadian.

Hasil observasi kegiatan PPL menunjukkan bahwa belum ada kontrol dari Unit Program Pengalaman Lapangan (UPPL) Fakultas Keguruan dan Ilmu Pendidikan (FKIP) Universitas Mataram 
dalam memberikan jaminan terhadap pencapaian kompetensi profesional dan pedagogi mahasiswa calon guru ketika melakukan kegiatan PPL di sekolah. Sebelum mahasiswa melakukan real teaching di sekolah, mahasiswa dibekali dengan kegiatan mikro teaching di kelas, namun hal ini belum menjamin mahasiswa yang mengikuti kegiatan PPL akan memiliki kompetensi pedagogi dan profesional sebagai calon guru. Ketika mahasiswa ditempatkan pada suatu sekolah untuk mengikuti kegiatan PPL, kontrol mutu dari lembaga untuk mengetahui kompetensi pedagogi dan profesional mahasiswa PPL belum pernah dilakukan. Sementara itu pelaksanaan PPL yang dilaksanakan di tempat lain tidak hanya terfokus pada kompetensi pedagogi dan profesional saja, akan tetapi sudah melalukan berbagai inovasiinovasi dengan menerapkan PPL yang berbasis Lesson study (Agustin, dkk., 2011; Awalindah, dkk., 2011; Haryoto, 2011; Hutami, dkk., 2011; dan Rokhmawati, 2011)

UPPL FKIP Universitas Mataram sebelum melakukan inovasi-inovasi dalam implementasi program pengalaman lapangan yang lain berkepentingan untuk memastikan bahwa mahasiswa yang melaksanakan PPL telah memiliki kompetensi seperti yang tertuang dalam UUGD. Permasalahannya ialah dalam melaksanakan kegiatannya UPPL FKIP Universitas Mataram belum pernah melakukan kegiatan pengukuran yang terkait dengan kompetensi mahasiswa. Padahal pengukuran tersebut sangat diperlukan untuk memastikan bahwa mahasiswa sebagai calon guru harus memiliki kompetensi yang dipersyaratkan oleh UUGD paling tidak kompetensi profesional dan kompetensi pedagogi. Sementara itu kompetensi kepribadian dan kompetensi sosial membutuhkan waktu yang relatif lama untuk dilakukan proses pengukurannya. Pelaksanaan PPL masih dirasakan kurang dan hanya cukup untuk melakukan pengukuran kompetensi profesional dan kompetensi pedagogi. Berdasarkan kondisi dan pertimbangan tersebut penelitian tentang kompetensi profesional dan pedagogi ini dilakukan.

Hasil penelitian ini diharapkan dapat dijadikan sebagai acuan bagi UPPL dalam mengembangkan kegiatan PPL pada masa-masa yang akan datang. Selain itu, pengukuran tentang kompetensi profesional dan pedagogi mahasiswa PPL dibutuhkan sebagai referensi bagi stakeholder dalam hal ini sekolah-sekolah mitra dalam melakukan penerimaan terhadap mahasiswa PPL.

\section{METODE}

Penelitian ini adalah penelitian deskriptif yang terkait kompetensi pedagogi dan profesional mahasiswa dalam pelaksanaan Program Pengalaman Lapangan (PPL). Subjek penelitian terdiri atas 16 mahasiswa Program Studi Pendidikan Biologi FKIP Universitas Mataram yang melaksanakan PPL pada tujuh sekolah (SMP dan SMA/ MA) yang ada di Kota Mataram dan Lombok Tengah.

Instrumen yang digunakan dalam penelitian ini terdiri dari angket kompetensi pedagogi dan kompetensi profesional. Angket disusun berdasarkan Peraturan Pemerintah No 74 Tahun 2008. Butir-butir yang digunakan dalam penyusunan angket terdiri dari perancangan pembelajaran, pelaksanaan pembelajaran yang mendidik dan dialogis, pemanfaatan teknologi pembelajaran, dan evaluasi hasil belajar. Keempat kompetensi tersebut kemudian dimodifikasi menjadi tiga aspek kompetensi yaitu kompetensi perencanaan pembelajaran, kompetensi dalam proses pembelajaran, dan evaluasi hasil belajar. Angket kompetensi pedagogi meliputi Instrumen Penilaian Perencanaan Pembelajaran (IPPP) dan Lembar Kerja Analisis Pembelajaran, sedangkan untuk kompetensi profesional menggunakan angket kompetensi profesional.

Kompetensi perencanaan pembelajaran, kompetensi dalam proses pembelajaran, dan evaluasi hasil belajar diaktualisasikan dalam Rencana Pelaksanaan Pembelajaran (RPP) melalui kegiatan real teaching. Data kompetensi pedagogi dikumpulkan melalui kegiatan real teaching yang dilakukan sebanyak tiga kali menggunakan Instrumen Penilaian Perencanaan Pembelajaran (IPPP) untuk mengetahui kompetensi pedagogi mahasiswa dalam perencanaan pembelajaran dan evaluasi hasil belajar, sedangkan untuk mengetahui kompetensi pedagogi mahasiswa dalam proses pembelajaran menggunakan Lembar Kerja Analisis Pembelajaran. Data kompetensi profesional dikumpulkan menggunakan angket yang meliputi dua aspek utama yaitu penguasaan materi secara luas dan mendalam, dan penguasaan konsep dengan metode disiplin keilmuan, teknologi atau seni yang relevan.

Data dalam penelitian ini dianalisis secara kuantitatif melalui analisis skor untuk ketiga angket yaitu Instrumen Penilaian Perencanaan Pembelajaran, Lembar Kerja Analisis Pembelajaran, dan angket kompetensi profesional. Skor 
penilaian untuk setiap aspek yang dinilai pada Instrumen Penilaian Perencanaan Pembelajaran (IPPP) menggunakan skor rata-rata seluruh mahasiswa yang dikategorikan menjadi 3 kategori penilaian, yaitu $2<S \leq 3$ (Sesuai Seluruhnya), 1 $<S \leq 2$ (Sesuai Sebagian), $S=1$ (tidak sesuai), sedangkan untuk Lembar Kerja Analisis Pembelajaran dikategorikan menjadi 4 kualifikasi penilaian, $3<S \leq 4$ (Sangat Baik), $2<S \leq 3$ (Baik), $1<$ $S \leq 2$ (Cukup Baik), $S=1$ (Tidak Baik).

\section{HASIL DAN PEMBAHASAN}

\section{Kompetensi Pedagogi Mahasiswa PPL}

Analisis kompetensi pedagogi mahasiswa PPL dikaji berdasarkan dua aspek, yaitu kompetensi pedagogi mahasiswa dalam perencanaan pembelajaran dan evaluasi hasil, dan kompetensi pedagogi mahasiswa dalam proses pembelajaran. Hasil analisis kompetensi pedagogi mahasiswa pada 32 aspek penilaian dalam perencanaan pembelajaran menunjukkan seluruh komponen utama RPP yang meliputi identitas mata pelajaran, standar kompetensi dan kompetensi dasar, perumusan indikator, perumusan tujuan pembelajaran, pemilihan materi ajar, pemilihan sumber belajar, pemilihan media belajar, metode pembelajaran, skenario pembelajaran, dan rancangan penilaian autentik berada pada kategori sesuai seluruhnya (Tabel 1).

Hasil penelitian menunjukkan bahwa kemampuan mahasiswa dalam menyusun RPP sudah baik. Hasil analisis kompetensi pedagogi mahasiswa dalam perencanaan pembelajaran menunjukkan bahwa kompetensi mahasiswa dalam penyusunan standar kompetensi dan kom- petensi dasar memiliki rerata skor tertinggi, yaitu 2,93. Hal ini mengindikasikan bahwa mahasiswa sudah mampu menjabarkan Standart Kompetensi (SK) dan Kompetensi Dasar (KD) sesuai dengan materi yang akan disampaikan. Penjabaran Standar Kompetensi dan Kompetensi Dasar penting dalam rencana pelaksanaan pembelajaran, karena berfungsi untuk mengembangkan potensi peserta didik (Mulyasa, 2010).

Hasil analisis kompetensi pedagogi mahasiswa dalam perencanaan pembelajaran juga menunjukkan bahwa rerata skor terkecil dari komponen RPP diperoleh pada perumusan tujuan pembelajaran dan pemilihan materi ajar dengan rerata masing-masing sebesar 2,60. Meskipun secara umum rerata skor tersebut berada pada kategori sesuai seluruhnya, kecilnya nilai tersebut jika dibandingkan dengan rerata skor komponen RPP yang lain mengindikasikan bahwa masih adanya perumusan tujuan pembelajaran yang tidak sesuai maupun sesuai sebagian dengan indikator. Begitu juga dengan pemilihan materi ajar, bahwa masih ditemukan sebagian kecil dari mahasiswa yang memilih materi ajar namun kurang sesuai dengan tujuan pembelajaran dan karakteristik peserta didik.

Hasil analisis kompetensi pedagogi mahasiswa dalam perencanaan pembelajaran terkait pemilihan media belajar memiliki rerata skor sebesar 2,75. Hal ini mengindikasikan bahwa sebagian besar mahasiswa sudah mencantumkan media belajar dalam RPP yang disusun dan secara umum sudah sesuai dengan tujuan pembelajaran, materi pembelajaran, pendekatan saintifik, dan karakteristik peserta didik. Pemilihan media

Tabel 1. Hasil Analisis Kompetensi Pedagogi Mahasiswa dalam Perencanaan Pembelajaran dan Evaluasi Hasil Menggunakan Instrumen IPPP

\begin{tabular}{llll}
\hline No. & Komponen RPP & $\begin{array}{c}\text { Rerata Skor Komponen } \\
\text { RPP }\end{array}$ & Kriteria \\
\hline 1. & Identitas Matapelajaran & 2,67 & Sudah lengkap \\
2. & Standar Kompetensi dan & 2,93 & Sesuai seluruhnya \\
& Kompetensi Dasar & & \\
3. & Perumusan Indikator & 2,75 & Sesuai seluruhnya \\
4. & Perumusan Tujuan Pembelajaran & 2,60 & Sesuai seluruhnya \\
5. & Pemilihan Materi Ajar & 2,60 & Sesuai seluruhnya \\
6. & Pemilihan Sumber Belajar & 2,65 & Sesuai seluruhnya \\
7. & Pemilihan Media Belajar & 2,75 & Sesuai seluruhnya \\
8. & Metode Pembelajaran & 2,82 & Sesuai seluruhnya \\
9. & Skenario Pembelajaran & 2,83 & Sesuai seluruhnya \\
10. & Rancangan Penilaian Autentik & 2,78 & Sesuai seluruhnya \\
\hline \multicolumn{2}{c}{ Rerata } & $\mathbf{2 , 7 4}$ & Sesuai seluruhnya \\
\hline
\end{tabular}


belajar penting karena media berfungsi dalam membuat hal-hal yang bersifat abstrak menjadi lebih konkrit (Sanjaya, 2008). Selain itu, rancangan penilaian autentik yang berperan sebagai alat evaluasi memiliki rerata skor 2,78. Skor ini cukup tinggi dan berada pada kriteria sesuai seluruhnya. Evaluasi penting dalam rencana pelaksanaan pembelajaran karena berfungsi untuk mengetahui ketercapaian siswa dalam menguasai tujuan yang telah ditentukan (Sanjaya, 2008).

Analisis kompetensi pedagogi mahasiswa dalam proses pembelajaran dikaji berdasarkan 44 aspek yang dibagi menjadi 10 kegiatan utama, yaitu apersepsi dan motivasi, penyampaian kompetensi dan rencana kegiatan, penguasaan materi pelajaran, penerapan strategi pembelajaran yang mendidik, penerapan pendekatan saintifik, penerapan pembelajaran tematik terpadu, pemanfaatan sumber belajar, pelibatan peserta didik dalam pembelajaran, penggunaan bahasa yang benar dan tepat, dan penutupan pembelajaran (Tabel 2).

Hasil analisis kompetensi pedagogi mahasiswa pada Tabel 2 menunjukkan bahwa sepuluh komponen tersebut memiliki rentangan rerata skor sebesar 3,01-3,64 dan berada pada kriteria sangat baik. Meskipun kesepuluh komponen penilaian dalam proses pembelajaran tersebut memiliki kriteria sangat baik, namun sebaran skor mahasiswa pada masing-masing aspek penilaian dalam 10 komponen penilaian beragam. Hal ini disajikan pada Gambar 1 sampai dengan Gambar 5.

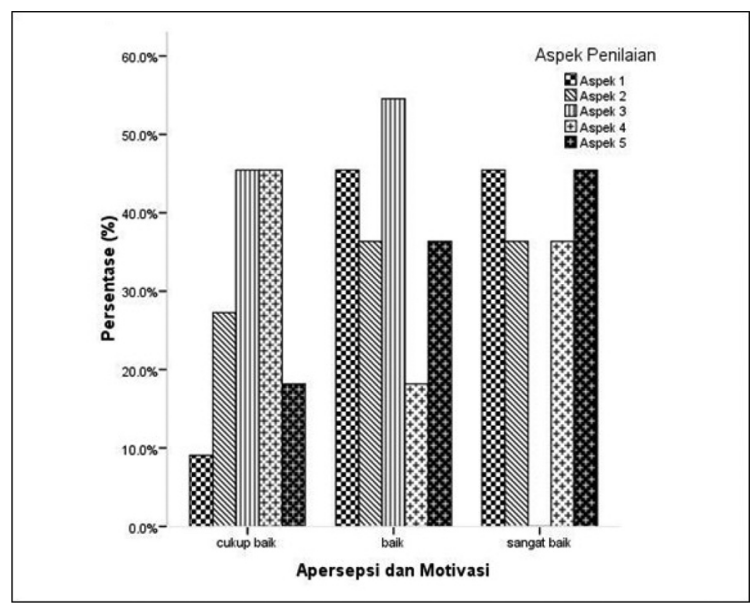

Gambar 1. Sebaran Skor Mahasiwa pada Lima Aspek Penilaian dalam Kegiatan Apersepsi dan Motivasi

Kelima aspek penilaian tersebut berada pada kriteria cukup baik, baik, dan sangat baik. Aspek penilaian 3, yaitu mengajukan pertanyaan menantang memiliki persentase tertinggi dan berada pada kategori baik, sedangkan yang paling rendah adalah aspek 1, yaitu menyiapkan fisik dan psikis peserta didik dengan menyapa dan memberi salam, berada pada kategori cukup baik. Berdasarkan Gambar 1 juga diketahui bahwa tidak satupun dari skor mahasiswa berada pada kategori sangat baik untuk aspek penilaian 3. Selain itu, sebagian skor mahasiswa masih berada pada kategori cukup baik dengan persentase yang cukup tinggi untuk lima aspek penilaian, meskipun secara umum untuk kegiatan apersepsi dan motivasi dalam proses pembelajaran berada pada kriteria sangat baik.

Tabel 2. Kompetensi Pedagogi Mahasiswa dalam Proses Pembelajaran Sesuai Kurikulum 2013

\begin{tabular}{llcl}
\hline No. & Aspek yang diamati & $\begin{array}{c}\text { Rerata Skor Aspek } \\
\text { Pengamatan }\end{array}$ & Kriteria \\
\hline 1. & Apersepsi dan Motivasi & 3,03 & Sangat baik \\
2. & Penyampaian Kompetensi dan & 3,32 & Sangat baik \\
& Rencana Kegiatan & 3,16 & Sangat baik \\
3. & Penguasaan Materi Pelajaran & 3,21 & Sangat baik \\
4. & Penerapan Strategi Pembelajaran & 3,01 & Sangat baik \\
5. & Penerapan Pendekatan Saintifik & 3,02 & Sangat baik \\
6. & Penerapan Pembelajaran Tematik & & \\
& Terpadu & 3,44 & Sangat baik \\
7. & Pemanfaatan Sumber Belajar & 3,44 & Sangat baik \\
8. & Pelibatan Peserta Didik Dalam & 3,64 & Sangat baik \\
9. & Pembelajaran & & \\
& Penggunaan Bahasa yang Benar & 3,27 & Sangat baik \\
10. & Kegiatan Penutup & 3,25 & Sangat baik \\
\hline
\end{tabular}


Berdasarkan hasil analisis kompetensi pedagogi mahahasiswa dalam proses pembelajaran pada kegiatan penyampaian kompetensi dan rencana kegiatan diperoleh rerata skor sebesar 3,32 dengan kriteria sangat baik. Hal ini didukung dengan tingginya persentase skor mahasiswa yang tersebar dalam kategori baik dan sangat baik pada dua aspek, yaitu menyampaikan kemampuan yang akan dicapai peserta didik, dan menyampaikan rencana kegiatan seperti kerja kelompok dan melakukan observasi (Gambar 2).

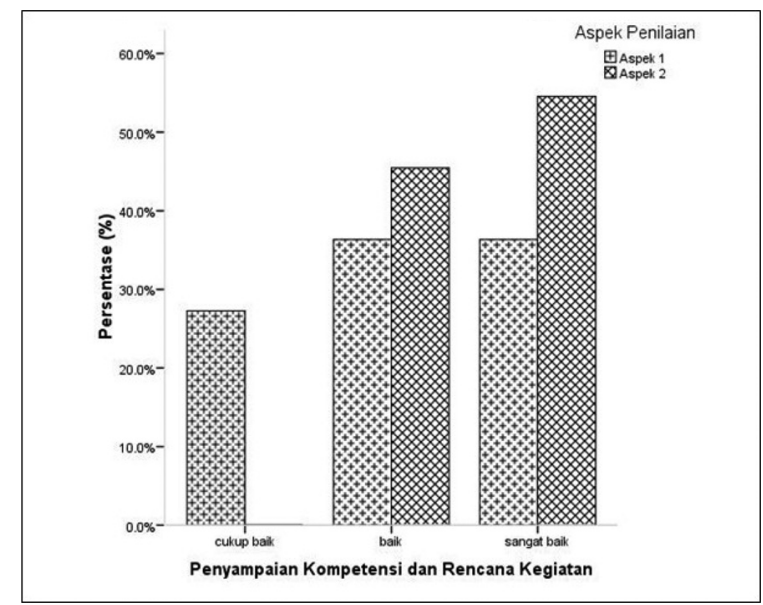

Gambar 2. Sebaran Skor Mahasiswa pada

Dua Aspek Penilaian dalam Penyampaian Kompetensi dan Rencana Kegiatan

Sebaran skor mahasiswa pada aspek penilaian dua berada pada kategori baik dan sangat baik, dan tidak satupun berada pada kategori cukup baik. Berdasarkan hasil analisis kompetensi pedagogi mahasiwa dalam hal penguasaan materi, diperoleh rerata skor masing-masing sebesar 3,16 dengan kategori sangat baik. Namun berdasarkan Gambar 3 diketahui bahwa aspek penilaian 4, yaitu menyajikan materi secara sistematis dalam hal penguasaan materi pelajaran sebagian kecil berada pada kategori kurang baik. Hal ini mengindikasikan bahwa masih ada mahasiswa yang masih sulit untuk menyusun materi pelajaran secara sistematis. Oleh karena itu, dosen sebagai fasilitator dalam pembelajaran PPL harus mampu membimbing mahasiswa dalam hal penguasaan materi pelajaran khususnya dalam menyusun materi pelajaran secara sistematis.

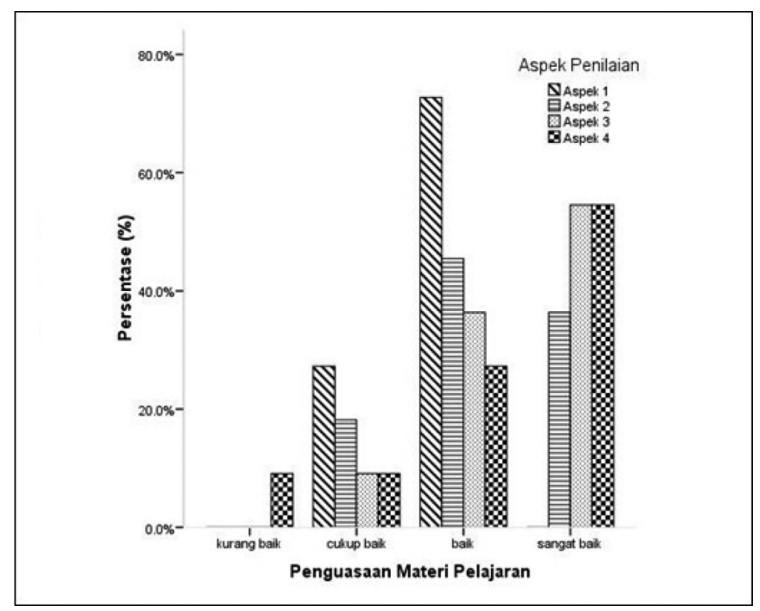

Gambar 3. Sebaran Skor Mahasiswa pada Empat Aspek Penilaian dalam Penguasaan Materi Pelajaran

Hal serupa juga dilaporkan oleh Napitulu (2014) yang menemukan bahwa penguasaan materi pelajaran mahasiswa calon guru Fisika di Universitas Tadulako berada pada kategori kurang baik. Lebih lanjut dijelaskan, dengan rendahnya penguasaan materi pelajaran berakibat pada rendahnya aspek kompetensi pedagogi mahasiswa dalam hal penerapan strategi pembelajaran dan penerapan pendekatan saintifik.

Hal yang menarik dari grafik rerata skor mahasiswa pada masing-masing aspek penilaian adalah sebaran skor dalam penerapan strategi pembelajaran (Gambar 4) dan penerapan pembelajaran tematik terpadu (Gambar 5) sebagian kecil dengan persentase berkisar antara $10-18 \%$ berada pada kategori kurang baik. Misalnya, pada aspek penilaian 3 dalam penerapan strategi pembelajaran, yaitu menguasai kelas sekitar $10 \%$ berada pada kategori kurang baik (Gambar 4), begitu pula dengan aspek penilaian 5 dan 6 dalam penerapan pendekatan saintifik, yaitu memfasilitasi peserta didik untuk menganalisis dan memberikan pertanyaan peserta didik untuk menalar sekitar $8-10 \%$ berada pada kategori kurang baik.

Hal yang sama dijumpai dalam aspek penilaian 2 dan 3 dalam penerapan pembelajaran tematik terpadu, yaitu menyajikan pembelajaran dengan memadukan berbagai muatan pelajaran dan menyajikan pembelajaran yang memuat komponen karakteristik terpadu sekitar 18\% berada pada kategori kurang baik (Gambar 5). 


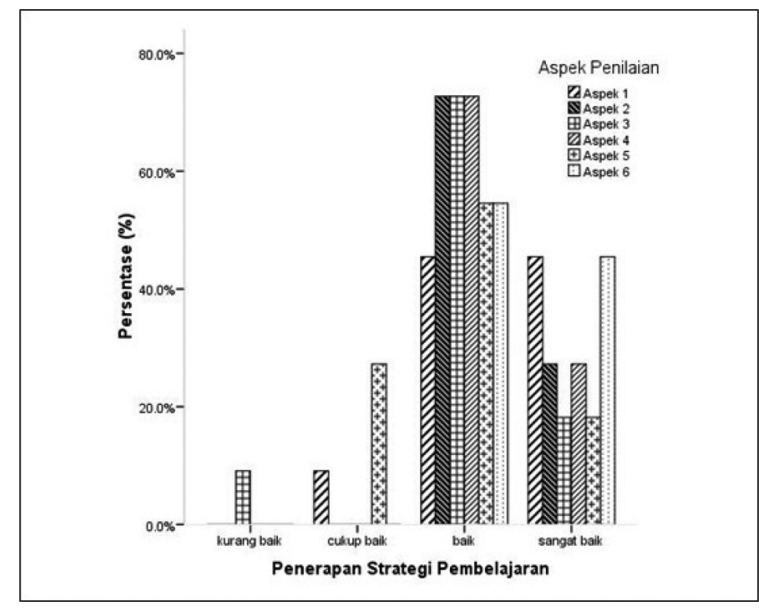

Gambar 4. Sebaran Skor Mahasiswa pada Enam Aspek Penilaian dalam Penerapan Strategi Pembelajaran

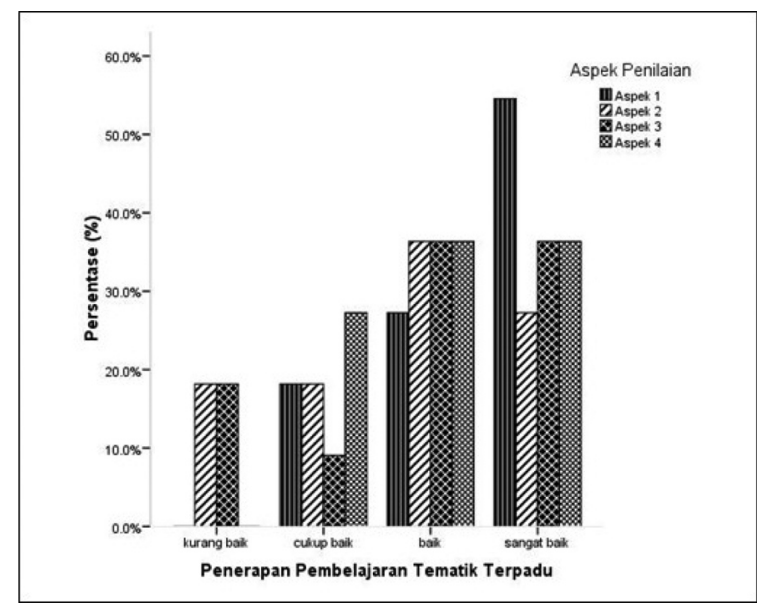

Gambar 5. Sebaran Skor Mahasiswa pada Empat Aspek Penilaian dalam Penerapan Pembelajaran Tematik Terpadu

Beberapa aspek penilaian yang masih berada dalam kategori kurang baik perlu mendapat perhatian khusus bagi dosen sebagai model bagi mahasiswa PPL untuk memberikan pembelajaran yang baik dalam kompetensi pedagogi di kelas. Secara umum kompetensi pedagogi mahasiswa PPL dalam perencanaan pembelajaran berdasarkan 44 aspek penilaian tergolong dalam kategori sesuai seluruhnya dengan rerata skor 2,74 (Tabel 4.1). Hasil ini berkorelasi secara tidak langsung dalam proses pembelajaran karena setiap aspek yang disusun dalam perencanaan pembelajaran menjadi pedoman dalam pelaksanaan pembelajaran. Hasil ini didukung oleh rerata skor kompetensi pedagogi mahasiswa dalam proses pembelajaran dengan rerata skor sebesar 3,25 dengan kategori sangat baik (Tabel 2).

\section{Kompetensi Profesional Mahasiswa PPL}

Hasil analisis kompetensi profesional mahasiswa PPL pada lima aspek, yaitu mampu mengaitkan antara konsep yang diajarkan dengan lingkungan kehidupan nyata, menyampaikan materi dengan mudah dipahami siswa, menerapkan metode saintifik sesuai materi pelajaran, menyampaikan materi dengan menarik dan menyenangkan, dan pemilihan bahasa yang baik dan mudah dimengerti siswa menujukkan bahwa kelima aspek tersebut memiliki rentangan rerata skor 3,01-3,55 dengan kategori sangat baik (Tabel 3).

Kemampuan mahasiswa dalam mengaitkan konsep yang diajarkan dengan lingkungan kehidupan nyata berada dalam kategori sangat baik dengan rerata skor 3,18. Kompetensi dalam mengaitkan konsep dengan lingkungan kehidupan nyata penting dalam proses pembelajaran untuk menguatkan, memperluas, dan menerapkan

Tabel 3. Hasil Analisis Kompetensi Profesional Mahasiswa PPL

\begin{tabular}{llcl}
\hline No. & Aspek yang diamati & $\begin{array}{c}\text { Rerata Skor Aspek } \\
\text { Pengamatan }\end{array}$ & Kriteria \\
\hline 1. & $\begin{array}{l}\text { Mampu mengaitkan antara konsep } \\
\text { yang diajarkan dengan lingkungan } \\
\text { kehidupan nyata }\end{array}$ & 3,18 & Sangat baik \\
2. & $\begin{array}{l}\text { Menyampaikan materi dengan } \\
\text { mudah dipahami siswa }\end{array}$ & 3,27 & Sangat baik \\
3. $\quad \begin{array}{l}\text { Menerapkan metode saintifik sesuai } \\
\text { materi pelajaran }\end{array}$ & 3,01 & Sangat baik \\
4. $\quad \begin{array}{l}\text { Menyampaikan materi dengan } \\
\text { menarik dan menyenangkan } \\
\text { Pemilihan bahasa yang baik dan } \\
\text { mudah dimengerti siswa }\end{array}$ & 3,09 & Sangat baik \\
\hline \multicolumn{2}{c}{ Rerata } & 3,55 & Sangat baik \\
\hline
\end{tabular}


pengetahuan dan keterampilan akademik siswa untuk dapat memecahkan masalah-masalah dunia nyata atau masalah-masalah yang disimulasikan (Trianto, 2009). Kompetensi profesional mahasiswa dalam penyampaian materi dengan mudah, menarik dan menyenangkan berada pada kategori sangat baik dengan rerata skor 3,27 dan 3,09. Pembelajaran yang mudah dan menyenangkan dalam proses pembelajaran akan menciptakan ketertarikan bagi siswa dan memberikan kesempatan kepada siswa untuk dapat berfikir dan bekerja (Miarso, 2008; Suparlan, 2008). Demikian halnya dengan penerapan pendekatan saintifik yang memiliki rerata skor sebesar 3,01 dengan kategori sangat baik. Penerapan pendekatan saintifik dalam pembelajaran dibutuhkan dalam rangka mengintegrasikan penguatan sikap, keterampilan dan pengetahuan.

Hasil yang diperoleh dalam penelitian ini memberikan gambaran bahwa kompetensi pedagogi mahasiswa PPL dalam hal perencanaan dan proses pembelajaran, serta kompetensi profesional perlu dipertahankan dan ditingkatkan, karena secara tidak langsung berperan dalam peningkatan mutu lulusan di FKIP Universitas Mataram. Dosen sebagai model dalam pembelajaran berperan penting dalam meningkatkan kompetensi pedagogi dan profesional mahasiswa PPL melalui pengembangan pembelajaran program PPL yang memberikan kesempatan lebih banyak bagi mahasiswa untuk melatih diri dalam meningkatkan kompetensi pedagogi dan profesional.

\section{SIMPULAN}

Berdasarkan hasil penelitian dan pembahasan akhirnya dapat disimpulkan sebagai berikut. (1) Kompetensi pedagogi mahasiswa PPL FKIP Universitas Mataram dalam perencanaan pembelajaran yang diukur berdasarkan 32 aspek penilaian memiliki rerata skor sebesar 2,74 dengan kategori sesuai seluruhnya. (2) Kompetensi pedagogi mahasiswa PPL FKIP Universitas Mataram dalam proses pembelajaran yang diukur berdasarkan 44 aspek penilaian memiliki rerata skor sebesar 3,25 dengan kategori sangat baik. (3) Kompetensi profesional mahasiswa PPL FKIP Universitas Mataram yang diukur berdasarkan 5 aspek penilaian memiliki rerata skor sebesar 3,22 dengan kategori sangat baik. Hasil penelitian ini dapat digunakan sebagai dasar pengambilan kebijakan dalam pengembangan program PPL bagi para pengambil kebijakan terutama yang ada di
FKIP Universitas Mataram, sekaligus sebagai referensi bagi stakeholder dalam hal ini sekolah terkait kompetensi pedagogi dan profesional mahasiswa PPL.

\section{UCAPAN TERIMAKASIH}

Ucapan terimakasih disampaikan kepada pengelola PGMIPAU (Program Guru MIPA Unggulan) FKIP Universitas Mataram yang telah memberikan bantuan pendanaan selama penelitian. Ucapan terimakasih yang sama disampaikan kepada Saudari Irmayani, S.Pd., dan Maesarah, S.Pd. serta Bapak/Ibu guru pamong di sekolah mitra yang telah membantu dalam pengumpulan data di lapangan.

\section{DAFTAR PUSTAKA}

Agustina, I.S., Herawati, S. \& Sulasmi, E.S. 2011. "Perbaikan Pembelajaran Melalui PPL Berbasis Lesson Study Berdampak Pada Motivasi dan Hasil Belajar Biologi Siswa Kelas X di SMA Laboratorium Universitas Negeri Malang." Prosiding Seminar Nasional Lesson Study 4 (ISBN 978-602-97895-5-3). FMIPA Universitas Negeri Malang. Malang. P: 311-319.

Awalindah, D.V., Susilo, H. \& Tenzer, A. 2011. "Pengembangan Motivasi dan Hasil Belajar Siswa Kelas XI IPA 1 SMA Laboratorium Universitas Negeri Malang Melalui Penerapan Praktik Pengalaman Lapangan (PPL) Berbasis Lesson Study." Prosiding Seminar Nasional Lesson Study 4 (ISBN 978-602-97895-5-3). FMIPA Universitas Negeri Malang. Malang. P: 7-14.

Haryoto, D. 2011. "Pelaksanaan PPPL Berbasis Lesson Study di Prodi Pendidikan Fisika FMIPA Universitas Negeri Malang." Prosiding Seminar Nasional Lesson Study 4 (ISBN 978-602-97895-5-3). FMIPA Universitas Negeri Malang. Malang. P: 270-273.

Hutami, P.A.V., Susilo, H. \& Tenzer, A. 2011. "Peningkatan Kemampuan Pedagogik Guru dan Hasil Belajar Siswa Melalui Implementasi Praktik Pengalaman Lapangan (PPL) Berbasis Lesson Study." Prosiding Seminar Nasional Lesson Study 4 (ISBN 978-602-97895-5-3). FMIPA Universitas Negeri Malang. Malang. P: 15-20. 
Miarso, Y. 2008. "Peningkatan Kualitas Guru dalam Perspektif Teknologi Pendidikan." Jurnal Pendidikan Penabur, Vol 7 (10): 66-76.

Mulyasa, E. 2010. Kurikulum Tingkat Satuan Pendidikan. Bandung: Remaja Rosdakarya

Napitulu, N.D. 2014. Analisis kompetensi mahasiswa calon guru fisika pada peer teaching berdasarkan kurikulum 2013 pada perkuliahan PPL. Jurnal Pendidikan Fisika Tadulako, Vol 2 (2): 23-28.

Rokhmawati, A. 2011. "Implementasi Praktik Pengalaman Lapangan Berbasis Lesson Study untuk Meningkatkan Keterampilan Mahasiswa dalam Memanfaatkan Media Pembelajaran." Prosiding Seminar Nasional Lesson Study 4 (ISBN 978-60297895-5-3). FMIPA Universitas Negeri Malang. Malang. P: 56-67.
Sanjaya, W. 2008. Perencanaan dan Desain Sistem Pembelajaran. Jakarta: Kencana Prenada Media Group.

Suparlan. 2008. Pembelajaran Aktif, Kreatif, Efektif, dan Menyenangkan. Bandung: PT. Genesindo.

Trianto. 2009. Mendesain Model Pembelajaran Inovatif-Progresif. Jakarta: Kencana Prenada Media Group.

Undang-undang Republik Indonesia Nomor 14 Tahun 2005 tentang Guru dan Dosen. Jakarta: Pemerintah Republik Indonesia.

Wardani. 1994. Program Pengalaman Lapangan. Jakarta: Depdikbud. 
